\title{
Statins are Potential Anticancer Agents for Multiple Myeloma
}

\author{
Jie Wei, Bing-Bing Cai and Dong Hong Deng* \\ Department of Hematology, The First Affiliated Hospital of Guangxi Medical University, China
}

*Corresponding author: Dong Hong Deng, Department of Hematology, The First Affiliated Hospital of Guangxi Medical University, Nanning, Guangxi, China

\begin{tabular}{|c|c|}
\hline ARTICLE INFO & ABSTRACT \\
\hline $\begin{array}{l}\text { Received: 幽 July 16, } 2019 \\
\text { Published: 輩 July 26, } 2019\end{array}$ & $\begin{array}{l}\text { Statins are inhibitions of the rate-limiting enzyme of the mevalonate pathway, } \\
\text { hydroxymethylglutaryl CoA reductase (HMG-CoA reductase). The statin agents including } \\
\text { simvastatin, lovastatin, rosuvastatin, and so on. They commonly are used to treat }\end{array}$ \\
\hline $\begin{array}{l}\text { itation: Jie Wei, Bing-Bing Cai, Dong } \\
\text { long Deng. Statins are Potential Anti- } \\
\text { ancer Agents for Multiple Myeloma. }\end{array}$ & $\begin{array}{l}\text { studies have shown that statins trigger tumor-specific apoptosis in certain cancers, } \\
\text { including multiple myeloma (MM). Here, we conduct this mini review to learn the statins } \\
\text { for treatment MM. }\end{array}$ \\
\hline
\end{tabular}
Biomed J Sci \& Tech Res 20(1)-2019. BJSTR. MS.ID.003393.

\section{Introduction}

Lipid and protein are essential materials for mammalian cells survival. Among lipid, cholesterol is the most important material which is used to synthesize the mammalian cell membranes and is fundamental material for cellular proliferation [1-2]. Decreasing the production of cholesterol and inhibiting protein prenylation may be the mechanisms for explaining that statins use can have an influence for proliferating and migrating of cells [3-4]. Basing on these theories, inhibiting the ability to assess cholesterol may have negative regulation in proliferation and migration for tumor cells. Further, statins can reduce the downstream production of mevalonate pathway, and statin use has a relationship with several potential anticancer properties [5-8] and decreasing risk of tumor relapse [9]. Further studies of statin anticancer have put into practice. At the cellular level, they observe that statins can halt the cell-cycle progression and make the tumor cells be more sensitive to radiation therapy [10-11]. The use of statins in such as colorectal cancer and acute myeloid leukemia which have been confirmed has an attribute to induce apoptosis in cancer cell lines in vitro data [12-13].

Moreover, the upregulation of HMG-CoA reductase has been observed in colorectal-cancer cells [14]. Thus, regular statin use may theoretically have chemo preventive activity against cancer and decrease cancer-associated mortality. The statins are potential drugs for treatment MM. Multiple myeloma is one of the hematological malignancies, which terminally affects the differentiated B cells in the bone marrow. Many new drugs have been recently introduced into the treatment protocols for this disease, improving the response ratio and increasing the survival of MM patients. Besides the standard treatment protocols, there are some researches conduct to observe the role of statins in MM. In 2003, Ralf Schmid Maier et. al. confirmed simvastatin could resolve cell adhesion-mediated drug resistance by geranylgeranylation of Rho protein and activation of Rho-kinase in MM [15]. In 2007, W. Wei-Lynn Wong et al. performed a study which showed that MM cell lines had a dichotomized response to lovastatin. There were 50\% MM cell lines which were sensitive to lovastatin-induced apoptosis, the rest were insensitive [16]. Based on this study, further research had been conducted. In 2010, W. Wei-Lynn Wong et al. exploited the mevalonate pathway to identify statin-sensitive MM. They concluded that dysregulation of the mevalonate pathway may provide the experimentally detectable marker which can distinguish patients who would benefit from statins for anticancer regimens [17].

In 2013, Adrianna Slawinska-Brych et al. performed a study, which had shown that combined simvastatin and thalidomide would enhance apoptosis of MM cells, the mechanisms included augmenting activated caspase 8 and 3, upregulating the activation of caspase 9 and 3, and enhancing JNK phosphorylation [18]. 
Many studies were performed in vitro, the efficacy of statins for anticancer in vivo do not have sufficient data to improve. In 2016, Kristen Marie Sanfilippo et al. performed a retrospective study that showed statins use had a relationship with reduced mortality for MM patients [19]. Although more and more studies have confirmed that MM patients can benefit from regular statins use, the conclusions only come from the vitro data or retrospective study. The actual statins anticancer mechanisms still insufficiently understanding. Further research should focus on whether the statins have the same efficacy and safety to anticancer in vivo, performing the randomized controlled trial, and identify the statins clear anticancer mechanisms. Competing Interests. The author declares that there are no competing interests.

\section{Funding}

The author(s) disclosed receipt of the following financial support for the research, authorship, and/or publication of this article: This study was supported by the First Affiliated Hospital of Guangxi Medical University.

\section{References}

1. Baserga R (1986) Molecular biology of the cell cycle Int J Radiat Biol 49: 219-226.

2. Lamond AI (2002) Review of: Molecular biology of the cell, $4^{\text {th }}$ Edition. 417: 383-383.

3. Fenton RG, Kung HF, Longo DL, Smith M (1992) Regulation of intracellular actin polymerization by prenylated cellular proteins. J Cell Biol 117(2): 347-356.

4. Herold G, Jungwirth R, Rogler G, Geerling I, Stange EF (1995) Influence of cholesterol supply on cell growth and differentiation in cultured enterocytes (CaCo-2). Digestion 56 (1): 57-66.

5. Fritz G (2005) HMG-CoA reductase inhibitors (statins) as anticancer drugs. Int J Oncol 27(5): 1401-1409.

6. Fritz G (2009) Targeting the mevalonate pathway for improved anticancer therapy. Curr Cancer Drug Targets 9(5): 626-638.

\section{ISSN: 2574-1241}

DOI: 10.26717/BJSTR.2019.20.003393

Dong Hong Deng. Biomed J Sci \& Tech Res

This work is licensed under Creative

Commons Attribution 4.0 License

Submission Link: https://biomedres.us/submit-manuscript.php
7. Jakobisiak M, Golab J (2003) Potential antitumor effects of statins. Int J Oncol 23(4): 1055-1069.

8. Mannello F, Tonti GA (2009) Statins and breast cancer: may matrix metalloproteinase be the missing link. Cancer Invest 27(4): 466-470.

9. Ahern TP, Pedersen L, Tarp M (2011) Statin prescriptions and breast cancer recurrence risk: a Danish nationwide prospective cohort study. J Natl Cancer Inst 103(19): 1461-1468

10. Mannello F, Tonti GA (2009) Statins and breast cancer: may matrix metalloproteinase be the missing link. Cancer Invest 27(4): 466-470.

11. Solomon KR, Freeman MR (2008) Do the cholesterol-lowering properties of statins affect cancer risk? Trends Endocrinol Metab 19 (4): 113-121.

12. Dimitroulakos J1, Nohynek D, Backway KL, Hedley DW, Yeger H, et al. (1999) Increased sensitivity of acute myeloid leukemias to lovastatininduced apoptosis: a potential therapeutic approach. Blood 93(4): 13081318.

13. Rao CV, Newmark HL, Reddy BS (2002) Chemopreventive effect of farnesol and lanosterol on colon carcinogenesis. Cancer Detect Prev 26(6): 419-425.

14. Hentosh P, Yuh SH, Elson CE, Peffley DM (2001) Sterol-independent regulation of 3-hydroxy-3-methylglutaryl coenzyme A reductase in tumor cells. Mol Carcinog 32: 154-166.

15. Schmidmaier R (2004) The HMG-CoA reductase inhibitor simvastatin overcomes cell adhesion-mediated drug resistance in multiple myeloma by geranylgeranylation of Rho protein and activation of Rho kinase. Blood104(6): 1825-1832.

16. Wong WW, Clendening JW, Martirosyan A, Boutros PC, Bros C, et al. (2007) Determinants of sensitivity to lovastatin-induced apoptosis in multiple myeloma. Mol Cancer Ther 6(6): 1886-1897.

17. Clendening JW, Pandyra A, Li Z, Boutros PC, Martirosyan A, et al. (2010) Exploitin Clendening JW, Pandyra A, Li Z, Boutros PC, Martirosyan A,g the mevalonate pathway to distinguish statin-sensitive multiple myeloma. Blood115(23): 4787-4797.

18. Slawinska Brych A , Zdzisinska B, Mizerska Dudka M, Kandefer-Szerszen M, et al. (2013) Induction of apoptosis in multiple myeloma cells by a statin-thalidomide combination can be enhanced by p38 MAPK inhibition. Leuk Res37(5): 586-594.

19. Sanfilippo KM, Keller J, Gage BF, Luo S, Wang TF et al. (2016) Statins Are Associated With Reduced Mortality in Multiple Myeloma. J Clin Oncol 34(33): 4008-4014.

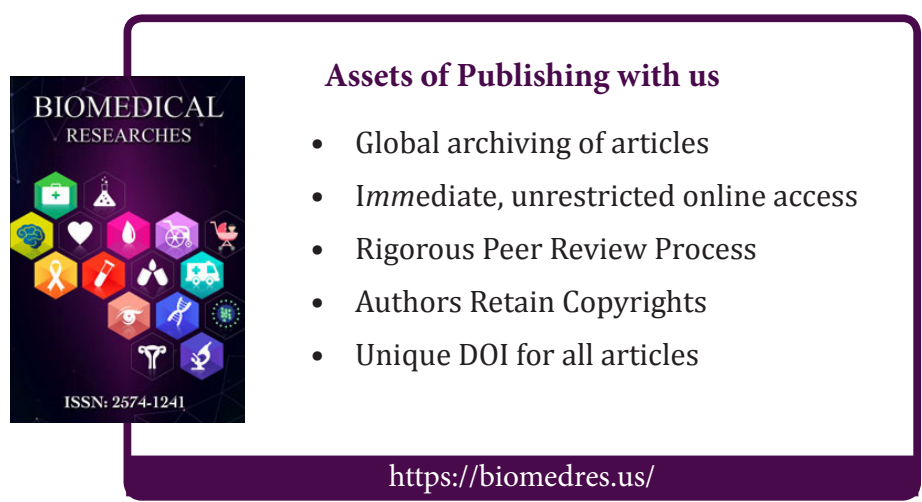

